\title{
バクトリア語文書から見たトハーリスターン在地の支配階層
}

\section{Local Dominant Classes in Tukhāristān Viewed from the Bactrian Documents}

\author{
宮 本 亮 $*$ \\ MIYAMOTO Ryoichi
}

\begin{abstract}
Due to new information from the Bactrian documents deciphered and published by Nicholas Sims-Williams, we can now research new subjects that have not previously been studied on the history, geography, and society of Tukhāristān in the pre-Islamic period. In this article, I perform a historical study on the local dominant classes in Tukhāristān by using the fruits of philological study on these Bactrian documents.

The local ruler in Tukhāristān is referred to as khar in the Bactrian documents. In the first chapter, I scrutinized all documents in which khar is mentioned and showed the following possibilities: there were a number of khars in Tukhāristān from region to region and their regional control changed with the times; apart from khar, there was shaho 'king' in this region and shaho was gradually replaced by khar; the khar's jurisdiction corresponded with the largest administrative division, which is referred to as shahro 'city' in the documents.

Kharagan, a word derived from khar is frequently mentioned in the documents, which is considered as an epithet for indicating belonging to a family of khar. In the second chapter, I examined local aristocratic classes who bore this epithet and highlighted the following: kharagan would have had private property and would have controlled an administrative division called a lizo 'citadel'; this characteristic is comparable to a landed class, which is called dehqān in Islamic sources; regarding labirobido, a title meaning 'chief scribe' born by a kharagan, one can compare this with an example in a Sogdian document, and this government post would have been of high degree.
\end{abstract}

キーワード：トハーリスターン, バクトリア語, 世俗文書, khar, kharagan

\section{I. はじめに}

イスラーム化以前の中央ユーラシア, とりわけパミール高原以西の諸地域の社会について, その 実態を知ることは極めて難しい。例えば，ユーラシア大陸の東西を結ぶ交易に従事したことで史上 に名高いソグド人の故郷ソグドでは，ソグド語を話す人々の社会が形成されていた。しかし，その 実態を知るための資料は，わずかにタジキスタンのムグ山から出土した 80 点程のソグド語世俗文書, ペンジケントやサマルカンドなどの都市遺跡に残された壁画や考古遺物などが知られているだけで ある。

* 日本学術振興会特別研究員 PD

Research Fellow of the Japan Society for the Promotion of Science

(C) The Society for Near Eastern Studies in Japan 
本稿で考察の対象となるトハーリスターンは状況がより厳しく, その実相を解明するための資料 は皆無に等しかった。しかし，90年代に発見され，近年刊行が終了した 150 点を越える4〜8世紀 のバクトリア語世俗文書群を利用することにより，ほとんど未知であった同地域の社会について考 察することが可能となった。

ただしここで注意すべきは, 現状, 文書の理解は, その解読者シムズ＝ウイリアムス唯一人の理 解に基づいており，今後それが改定される可能性が十分に想定されるということである。それで も, この状況を念頭に置いた上で, 解読者の理解を確認しつつ歴史的な考察を行うことは可能であ る。そこで本稿では, バクトリア語文書を利用したトハーリスターンの社会像解明のための第一歩 として，在地社会の支配階層について考察する。

\section{II. トハーリスターンの支配階層}

\section{1. 在地の支配者 khar とその周辺}

i) kharの事例

630 年, インドへ向かう途上トハーリスターンを通過した玄奘の報告に基づく『大唐西域記』（以 下『西域記』）によれば, この地域には，それぞれに首長（原文「君長」）を戴く 27 の国があり，そ の上に支配勢力として突厥がいた。この「君長」に当たるのが, バクトリア語文書中でkhar と呼ば れる在地の支配者であると考えられる。

バクトリア語文書が書かれたほぼ全ての時代にわたって存在したこのkharは, 文書中では, 単独 で「khar」と言及される他に,「ローブのkhar」, および「Pidud/Pyudのkhar」という, 地名と共に

（1）文書群の概要は, Sims-Williams 1997; 吉田 2013 を参照。バクトリア語文書中で使用されている, いわゆる バクトリア紀元については, Sims-Williams and de Blois 2018, 9-46を参照。本稿における紀元の換算はドゥ・ブ ロワが提示する 223 年開始説を採用している (Cf. de Blois 2008)。バクトリア語文書のナンバリングについて簡 単に説明すると，BD I 2 では，契約文書やレシートなど，紀年を有するものには，古い順に A Y, 年代不明の断 片には aa ae, an, リスト・帳簿には af am の記号が振られている。主に手紙を収録したBD IIでは, 基本的に法 律・経済文書に登場する人物との対応関係に基づき文書が分類され，ba jjの記号が振られている。例えばDoc. ba は, Doc. B の年代に近い手紙ということである。また, 年代の推測できない手紙は xa xt とある。ただし最近になっ て, 年代不明の文書に関しても, 字体や言語的特徵, 緅りの分析から大まかな年代が与えられた。詳細はSimsWilliams and de Blois 2018, 47-79を参照。文書の大部分はヒンドゥー・クシュ山脈北麓のローブ（現ルーイ）に 存在した在地の王国の文書庫に由来すると思しきものであり，ローブ以外には，その北東に位置するカダグスター ン，および西に位置するグーズガーンに由来する文書も知られている。最近になって, ヒンドゥー・クシュの南側 に由来すると思しき文書も発表された（Sims-Williams 2015）。

（２）バクトリア語はその表記にギリシア文字を用いることから，母音の長短など正確な発音が判明していない語が 多く, カ夕カナ表記にすることが困難である。本稿では基本的にシムズニウイリアムスによる転写を用い，原語の 提示が必要な際には, ギリシア文字に対応するラテン文字で機械的に転写し, 斜体で表記する。

（３）桑山 1987, 9-10。玄牀の出発年に関してはde la Vaissière 2010 を参照。

（4）古代イラン語の*xšāariya-「支配者」に由来するkharという語には*šēerという形もあり，イスラーム時代の文 献に見える šr r/syr はこれを写したものと考えられている(Sims-Williams 1997, 15-16)。また, 『西域記』がカーピシー の王を「刹利」種と伝えているのも，同じ語を写したものと考えられている（吉田 2013, 60 n. 49）。ドゥ・ブロワは,

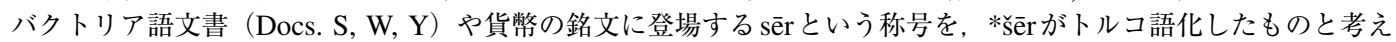
ているが，筆者はsêrがkharよりも上位の階層に属する存在であった可能性が高いと考えており，ドゥ・ブロワの 説を受け入れていない。なぜなら, serrが貨幣を発行し得た存在である一方, 現在までkharの発行した貨幣は全く 知られていないからである (de Blois apud IPNB II/7, no. 428; Vondrovec 2014, 521-522)。 


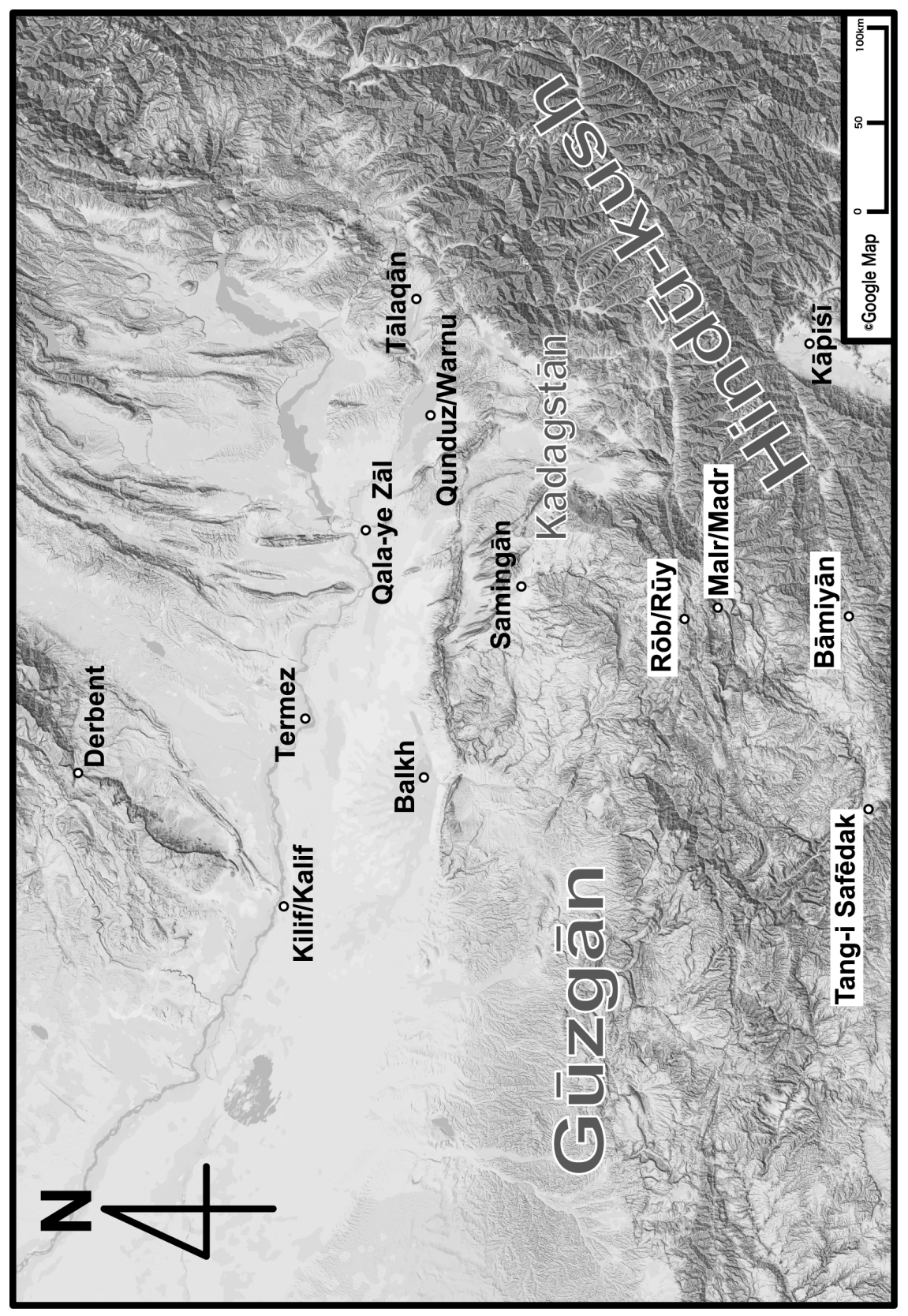

トハーリスターン全域図

現れる事例が $2 つ$ 存在する。さらに,「マルル/マドルのkhar」という銘文を持つ捺印物も知られて

（ 5 ） kharが単独で言及される文書については, BD II, 277bを参照。シムズ＝ウィリアムスは, この kharが「特にロー ブの支配者」を指すと述べているが，単独で現れる事例を網羅的に調べると，それが確実に「ローブの khar」を 指していると断言できるものがほとんど存在しない点は注意が必要である。ここで全ての事例を検討することはで きないが，4世紀後半から 5 世紀中頃に書かれたと考えられている手紙（BD II, Doc. xn; cf. Sims-Williams and de Blois 2018,77）に現れるkharは，手紙の内容にローブについての言及があることから，「ローブのkhar」を指して いる可能性が高い。しかし，それ以外は，いずれもローブのkharを指しているかどうか判断できないか，あるい はそうではない可能性がある。例えば, Warnuで書かれた 602年の契約文書（Doc. L）に登場する保証人は, 「Warnu 
いる( 6 (

これらは，言及されている各土地にいたkharのことを指しているように見える。「ローブのkhar」 がローブにいたkharであることは明らかである。「Pidud/Pyudのkhar」が保証人として登場する 662 年の契約文書（Doc. O）は，アム・ダリア河岸のカルフ（ケリフ）辺りで書かれたものであり， その内容から, 文書が書かれた当時, この地域はグーズガーンに含まれていたと考えられる。つまり， その所在地が比定されていないとはいえ，「Pidud/Pyudのkhar」は，この地域にいたkharのことを 指しているに違いない。

最後の「マドル／マルルのkhar」に関しては，その銘文を持つ捺印物が存在する，つまりこの銘 文を刻んだ印章が存在したことを考えれば，ローブとの距離がそれほど離れていないとはいえ，こ の地にkharが存在したとみなすべきだろう。このマドル／マルルで517年に書かれた契約文書(Doc. J) は,「kharの法廷で」書かれたものである。この場合, kharはマドル/マルルのkharを指してい ると考えるのが最も自然である。しかし，Doc. Jからおよそ 200 年後の 712 年に同じ土地で書かれ た契約文書（Doc. U）は，「ローブのkharの法廷」で書かれたと記されている。つまり，書かれた 場所はマドル／マルルであるが，そこを管轄していたのは，マドル／マルルのkharではなくローブ のkharなのである。これらの事例を勘案すると, マドル／マルルにも kharが存在していたが, どこ かの時点でローブの kharの管轄範囲に組み込まれと考えるべきだろゔ。 Doc. Jよりも100年ほど後 (629年) に, サミンガーンで書かれた契約文書 (Doc. N) では, マドルの住人のTakなる人物が,「ロー ブの kharの僕」と呼ばれているので，マドル／マルルがローブの kharの管轄範囲に組み込まれたの はこれ以前と考えられる。

ii) khar と王

ところが, マドル／マルルのkharに関してはさらに難しい問題がある。というのも，先に言及し たDoc. Jでは，契約の当事者が「マルルの住人で，王（shaho）の僕」と述べられており，マドル /マルルには, kharとは別に，「王」が存在したと考えられるからである。この「王」が一体どの ような存在であったのかは，バクトリア語文書に登場する「王（shaho/shao）」の事例を通覧して

出身で, kharのしもべ」と呼ばれており，このWarnuは，イスラーム時代の文献でワルワーリズ Warwāliz と呼ばれ， 現在のクンドゥズに比定されている（Sims-Williams 1997, 16-17 n. 28）。ここに見えるkharが「ローブのkhar」を 指す可能性は低いだろう。「ローブの khar」に言及する文書については, BD II, 260bを参照。「ローブのkhar」と いう銘文を持つ捺印物も知られている（SARC 2, AA 4.3, AA 5.4）。

( 6 ) Lerner et al. 2009, 217-218; SARC 2, AA 4.1, AA 4.2。マルル Malr とマドル Madrは同じ地名のヴァリアント であり，現在もローブの南方にその名を残している（BD II, 230a）。

（７） シムズ＝ウィリアムスは，筆者が「kharの」と訳したkharanoという語を kharの複数形であると考えている $\left(\mathrm{BDI}^{2}, 48\right.$; cf. BD II, 277b)。しかし筆者は, この語が, 形容詞を形成する接尾辞-anoが kharに付された形である と考えている。その根拠は次註を参照。

( 8 ) ここでもシムズ=ウイリアムスは，筆者が「ローブのkharの」と訳した rōbokharanoという語を「ローブの khar」の複数形と考えている（BDI ${ }^{2}, 106 ;$ cf. BD II, 260b)。しかしこれも，接尾辞-anoが付された形容詞形である と考えられる。なぜなら，バクトリア語の法律・経済文書のうち，最も一般的なフォーマットは，縦長の媒体 (多 くは羊皮紙）の上下に同じ内容の文章を記し，上側だけを巻き，封をするというものだが，ここで問題となってい るrōbokharanoが上側に見えるのに対し，対応する下側では，rōbokharaggo，つまり rōbokharoに形容詞を形成す る接尾辞-aggoが付された形になっているからである。筆者の推測が正しいとすれば, 先のDoc. Jの事例も同様で ある可能性は十分にある。

（９） シムズ=ウイリアムスは，ローブのkharの統治権が及んでいた範囲を，北はサミンガーン，南はカフマル ドあたりまでであったと述べているが，時代によってその統治範囲が変化した可能性は当然考えられる（SimsWilliams 1997, 14)。 
も良く分からない。

Doc. Jが書かれた時代（6世紀）のトハーリスターンで「王」と呼ばれる存在としてまず思い浮 かべるのは，バグラーン平原を中心とした地域に，恐らくサーサーン朝支配の影響のもと，4世紀 後半に出現した「カダグスターン」と呼ばれる地域の支配者,「カダグの王（kadagano shao）」で あろうう。ただし，このカダグの王は5世紀頃の手紙（Doc. ja）に登場するものの，残念ながらこの カダグの王とDoc. Jの王を直接結びつけ得る証拠は何も存在しない。

次に考えられるのは, クシャーン朝滅亡後, 当地を支配していたクシャーン・シャー (koshanoshao) である。この存在もバクトリア語文書中に在証例（Doc. ba）があるが, クシャーン・シャーを名乗 り当地を支配した諸王は，3〜4世紀にかけて存在したと考えられており，Doc. Jに見える「王」と 直接結びつけることはできない。あるいは, クシャーン・シャーの末裔が何らかの形で当地に残存 していた可能性は排除できないが，それを証明することもできない。

結局のところ, 問題の王が何者であるのか, khar と王との関係がどのようなものであったのかは 何も分からない。支出簿と考えられているDoc. alの末尾に見える「私は毎月与えた。エフタルの君 主，あるいは王のため，‥のため (以下欠)」という文言からは, 王は何らかの物資を受領する立 場にあったことが窺われるが, それ以上のことは分からない。ただし，「王」の存在自体は, Doc. C（380年）と近い時代に書かれたと考えられている2点の手紙（Docs. cd, cg）にも言及されてい るので, Doc. Jよりも古い時代から存在していたことは確かである。

これに関しては，王という語から派生した「王の（shaogano）」という形容詞も興味深い。この 形容詞は，1つの用例を除き，全て契約文書の末尾に現れ，同じ文脈で用いられている。すなわち， バクトリア語の契約文書の末尾には違約罰への言及があり，罰金を「王の庫（shaogano gazno）」 へ支払うという文言が見られるのである。そして，「王の庫」へ罰金を支払うという文言が記され ているのは, Doc. A (332年), Doc. C (380年), Doc. J (517年), Doc. L (602年), Doc. aa (年 代不明) であり，Doc. Lよりも新しい文書には「王の庫」への言及は全く見られなくなる。そして， 次に違約罰への言及が見えるDoc. N（629年）では，罰金は「ローブのkharの庫」へ支払うことに なっている。

（10）カダグスターンという地域については, Sims-Williams 2008, 98-99; Sims-Williams 2009; 宮本 2014, 85-111を 参照。シムズニウィリアムスの翻訳に従えば，問題の手紙は，「高名で繁栄したエフタルのヤブグの kadag-bid，カ ダグの王 (namooi[nda]do abzodo i-ēbodlo i[a]b[go] kadagobi[do ka]dagano shao)」であるKilmanなる人物から 出されたものである (BD II, 124)。ただし上の翻訳には, エフタルのヤブグと, カダグスターンの支配者が帯びた 称号 kadag-bidを同格とみなす可能性が残されている。なお，カダグの王は 8世紀後半の文書（Doc. Y）にも登場し， そこでも称号の羅列をどう解釈するかが問題となっている（吉田 2013, 54 n. 34）。

（11） Doc. jaの年代については, Sims-Williams and de Blois 2018, 72-73を参照。

(12) クシャーン・シャーについては，ひとまずde la Vaissière 2016; Schindel 2016を参照。

（13）Doc. cdには,「(貴方は）王の栄光, そして, 私が王の手から食したパン（と）塩（のこと）を知らねばならない」 という文言が見える。中央アジアのテュルク諸語に見られる「パンと塩」の供与とそれに報いることに関わる表現 については, 濱田 1993, 288-290を参照。一方Doc. cgには, 「Sang-Khirdの内戚（も）外戚（も）一族も王の僕で あり」という文言が見える。

（14）1つの例外とは，前註で言及したDoc. cdに見える「王の栄光（shēganigo faro）」である。

（15） Doc. aaの年代について，詳細はSims-Williams and de Blois 2018, 65を参照。

（16）ただし，Doc. L以前の文書が全て「王の庫」に言及しているわけではなく，1点例外があり，Doc. F（470年） では「Bredagの庫」に罰金を支払うとある。そして, グーズガーンで書かれた文書（Docs. Nn, O, R, S, Tt, Uu）, およびDoc. Q（671年）を除き, Doc. T（700年）以降の文書（Docs. T, U, V, W, X) では, 全てこの「Bredag の庫」 に罰金を支払うことになっている。ただし，このBredagが何かは良く分かっていない（BD II, 205a; IPNB II/7， no. 105)。ちなみにDoc. Qでは「裁判官の庫」に支払うとある。 
上述した内容をもとにすれば，バクトリア語文書に見られる問題の「王」は古くに起源を持つ存 在であり，トハーリスターンの社会において kharとは異なる何らかの権限を有していたが，その存 在は徐々にkharに取って代わられたと推測できるかもしれない。そして，それはマドル／マルルに 居所を有していたのかもしれない。あるいは，『西域記』に見える「数百年よりこのかた，王族は 嗣を絶ち」という記述を考慮に入れれば，もはや外部からやってきた人にはその存在も分からない ような, 名目上の存在となっていたのかもしれない（桑山 1987, 10）。

iii）kharの権限と行政区画

いずれにしても，ローブのkharが外来の支配勢力と関係深い様々な称号を帯びていたことから 判断すれば, kharがトハーリスターンの在地社会における最上位の存在であったことは間違いない だろう。ただし，kharに関しては，世襲の場合があったことが指摘されているものの（IPNB II/7, no. 421, 536), 文書の内容からは，この在地支配者が社会において実際にどのような権限を有して いたのかはほとんど分からない。土地の購入契約書Doc. V（729年）において，「ローブのkharが Baradikan（家）の主に与えた地所」という文言が見えることから（BD I ${ }^{2}, 118 ）$, khar は土地を供 与する権限を有していたのかもしれないが, 古い時代の手紙（Doc. bg）には, サトラップ（sharabo） の称号をもつ人物が, 次節で述べる貴族階級（kharagan）の1人に土地を与えたことが記されており， 古い時代にはkharが土地の供与に関わっていなかった可能性もある。

トハーリスターンの北に位置するソグドでは，オアシス国家の領主が絶対的な権力を有しておら ず，その領主はイスラーム時代の文献においてディフカーンと呼ばれる地主階級出身で，世襲の場 合もあれば, 有力者たちによって推挙されたり廃絶されたりした場合もあるといゔ。トハーリスター ンのkharは, ソグドにおけるオアシス都市の領主と同様の存在であったと推測することが可能であ る。ただし, ソグドでは領主が貨幣を発行していたのに対し, トハーリスターンでは kharの発行し

（17） ヤズデギルド2世の死後，サーサーン朝でペーローズとオフルマズド3世との間に王位継承争いが起きた時， ローブのkhar は時に「ペーローズに忠実な」, 時に「オフルマズドによる栄光」という敬称を帯びており，これは kharが時勢を筧いそれぞれの側についていたことを示していると考えられている（BD II, 88-91; cf. Sims-Williams 2008, 93-94)。また，エフタル支配の時代には，kharは，「栄光もてるエフタルのヤブグ（のもとにいる）ローブ のkhar, エフタルの君主の書記, トハーリスターンとガルチスターンの裁判官」と名乗っている（BD II, 126-127; cf. 吉田 2013, 57)。なお， シムズ=ウィリアムスは，当初「エフタルのヤブグ」と「ローブの khar」を同格に訳し ていたが, 吉田豊の指摘を参考にして, 現在は上のように翻訳を改めている。この改訂は, 2017年 8 月 29 日〜 31 日にエトヴェシュ・ロラーンド大学 (ブダペスト) で開催されたワークショップ, Hunnic Peoples in Central and South Asiaの参加者に配布された資料集に揭載されたものである。詳細は，近い将来刊行される資料集を参照され たい (Cf. Yoshida 2003, 158a)。さらに突厥の支配下に入って以降は,「栄光のもとに繁栄したカガンの tapaghligh iltäbär」と名乗っており（BDI², 68-69, 84-85, 88-89; cf. Sims-Williams 2011, 24），これらの尊称は，それぞれの 支配者からローブの kharに与えられたものであろう。

（18）トハーリスターンに扔けるサトラップに関する情報は極めて少ない。パルティア語からの借用語と思われるこ の語の用例については，BD II, 283bを参照。サーサーン朝による支配の文脈で登場したと考えられる「ペルシア のサトラップ」に関しては, BD II, 253a; Sims-Williams 2008, 91-92を参照。

（19）吉田 1999, 47; 吉田 2011a, 32-33。ソグドでは, 領主はxwBw と呼ばれ, サマルカンドの領主がソグド全体の 王（MLK' = 'xšy $\delta)$ を名乗った。8世紀前半にペンジケントの領主であったデーワーシュティーチュがディフカー ン階層に属していたことについてはMarshak 1994 を, デイフカーン階層についてはTafazzoli 1994; Tafazzoli 2000, 38-58を参照。デイフカーンについては, 近年コータンで発見された 8-9世紀頃のユダヤ・ペルシア語文書に見え る事例が興味深く，そこでは，ディフカーンはコータン王を指すと考えられている（吉田 2017, 273-275）。

（20） kharの地位については, 手紙の書式も参照（吉田 2013, 58-59）。注5において,「ローブのkhar」の銘文を 持つ捺印物に言及したが，ソグドでは，在地の支配者が印章を保持し，自ら手紙に封印したことが知られている (Livshits 2015, Doc. A-16)。 
た貨幣は知られていないため，両者の有していた権限には大きな違いも見られる。

kharに関わる最後の問題として，kharの管轄した領域とバクトリア語文書に見える行政区画との 関わりに言及しておきたい。本節の冒頭で，kharと地名とが併記されている事例を挙げたが，そ れらのうちローブは，バクトリア語文書中でshahro と呼ばれ（Docs. A, C)，マドル／マルルは, shahroあるいは odago と呼ばれている（Docs. J, U)。ローブの事例だけを見れば, 1 人のkharが管 轄する領域が1つの shahroであったと考えることができる。

一方マドル／マルルに関して，筆者は以前，この場所がDoc. J (517年) ではshahro と呼ばれ

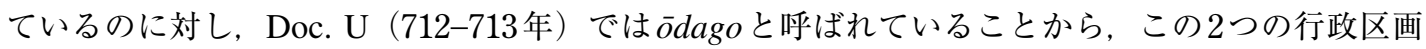
を示す語は, 指示範囲は同じであるが用いられた時代が異なる, つまり shahroは何らかの要因で odagoへと変化したと考えた（宮本 2015, 301; cf. BD II, 284a）。もしそうであるならば， kharの管 轄領域は odago とも重なることになる。しかし，上述したように，マドル／マルルにはもともと kharが存在したが，その後ローブの kharの統治下に組み込まれた可能性があることを考慮に入れる と, 単純にōdago shahro と同規模とはみなせないかもしれない。つまり，もともとは 1 人の khar が統治する shahroであった地域が，別のkharの統治下に組み込まれることにより， odago と呼称を 変え, shahroよりも下位のカテゴリーとみなされるようになった可能性もある。明らかにローブの kharの管轄下にあったサミンガーンが，shahroではなくódago と呼ばれていることも（Docs. N, P,

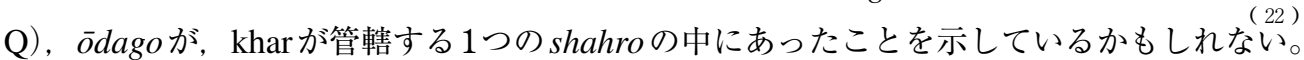

ところで, 『西域記』が伝えるトハーリスターンの 27 国の1つ䋁露悉泯健国は，ローブ（紀露） とサミンガーン (悉泯健) を指すと考えられており，この国の範囲はローブの kharの統治圈と重な る（桑山 1987, 13, 142-143）。つまり，玄牀の時代に関しては，1人の kharが管轄する地域が，1つ の「国」に相当していたと考えられる。

\section{2. 貴族階層（kharagan）}

バクトリア語文書には，kharagan という語が度々登場する。この語は，kharに形容詞を形成する 接尾辞-ano/-ganoが付された形であり，原義は「kharの息子／子孫」となるが，実際にはkharの一 族に属していたことを示す家名やエピセットのようなものであったと考えられている（IPNB II/7, no. 421, 515)。つまり，このエピセットを持つ人間は，在地社会における貴族階層に属していたと

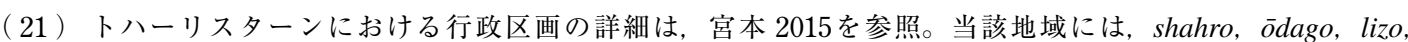
andago という4つの行政区画が存在した。筆者は 4 つ行政区画を示す語を日本語に訳す際，シムズ＝ウイリアム スの翻訳 (それぞれ, “city”, “district”, “fortress”, “borough, sub-district (of a city)”)に従い, それぞれを「まち」「地区」 「城些」「街区」とした（Cf. BD II, 191b, 227b, 281b, 284a）。しかし，「まち」に関しては，サーサーン朝期の印章・ 捺印物に見られる shahrが「州」と訳されていることを考慮すれば, トハーリスターンのshahroも「州」ほどの意 味であったと考えるべきかもしれない（Cf. Gyselen 1989; Gyselen 2002; Gyselen 2007)。筆者は, 「町」という漢 字からイメージする現在の比較的小規模な行政区画と区別するため，平仮名で「まち」という訳語を用いたのだが， それでも混乱をきたす可能性があるため, 本稿ではshahro とódagoは, バクトリア語の表記をそのまま用い，用 語をどのように解釈・翻訳するかについては，稿を改めて再検討したい。

（22）もしそうであるとすれば，サミンガーンはもともと shahroであったのかもしれない。ただし今のところ， shahroの用例が古い時代の文書に集中し，7世紀後半以降の文書に一切見られないことは注意しておかねばならな い。

（23）バクトリア語文書と一部時代の重なる新出のアラビア語文書に言及されるこの地のアミールの管轄範囲が, ローブのkharのそれと重なっていることがジェフリー・ハンによって指摘されている（Khan 2007, 21）。なお， kharの命令で行動していたと思しき官職として, 執務官（fromalaro）がいるが, これについては別稿を準備して いるので, そちらを参照されたい。 
考えられる。

バクトリア語文書中に10名登場する kharaganは, 様々な職名を帯びており, 共通の特徵を見出 すことは難しい（IPNB II/7, no. 98 iii, 162, 272 ii, iii, 282 i, 285 ii, 376, 421 i, 524, 529 ii, 546 xiii）。 ただし，kharaganの Khwadew-wanindが，Rizmと呼ばれる地域の草原に土地を獲得し（Doc. bg）, さらに羊飼いを所有していることから（Doc. ba），kharaganが私有地を有していた可能性がある。

また, kharaganのNawazが，ローブへ人を送っていること（Doc. cf），さらに，バーミヤーンの 城砦から離れた人物をNawazのいる城些で受け入れて欲しいという手紙を受け取っていることか ら (Doc. cg)，この人物がどこかの城砦で活動していたと推測できる。そして，Khwadew-wanind と Nawazが共通して「城砦長（lizobido）」という職名を有していることも興味深い（Cf. IPNB II/7， no. $524,282 \mathrm{i})$ 。これらを考慮に入れれば，両者に共通する点として，kharがいる土地から離れた別 の場所で活動し，私有地を有し，城砦という行政区画を管轄していた点を挙げることができる。

私有地を持ち, 在地の支配者と深い関係を有していたという点を重視すると, トハーリスターン におけるkharaganは，先に言及したディフカーンと呼ばれる地主階級と比較できるのではないだ ろうか。前節でkharが世襲であった可能性に言及したが，そこで想定されている父子関係は具体的 には次のようなものであった：Sart kharagan —ローブのkhar, Khude-band Sartan（i.e. Sartの息 子 Khude-band）ーローブのkhar, Sart Khudebandan（i.e. Khude-bandの息子Sart）。ここで世襲 と言ったのは，後半の 2 人（Khude-band Sartan とSart Khudebandan）の父子関係を指しているが, Khude-band Sartanの父がkharaganであったことは注目に值する。なぜなら，これは kharaganの中 からkharが輩出されていた可能性を示しており，ソグドにおける領主とディフカーンとの関係を想 起させるからである。

しかし, kharaganを名乗る者は他にも8名おり，それらの人物は「城砦長」とは異なる職名を有 している。例えばZu-wanindなる人物は「倉庫管理人」, Muzdという人物は「穀倉番 (kandogo-lēro)」 という職名を持っているが（Docs. Aa, B, G, H)，これらの職名はここに言及した文書にしか現れず， その具体的な職掌は不明である。また,「書記長 (labirobido)」という職名を持つOrmuzdなる人物 もいる (Doc. eg)。書記長も，その存在が文書中に言及されることは少なく，実態はほとんど不明

（24）次に述べるNawazが土地を要求する文書も知られており（Doc. ci）, このことも筆者の推定を補強する材料と なる。

（25）別の文書には, kharaganの Khwasrawが, Palag という城砦（所在地不明）から出て行ったことが記されてお

り (Doc. cb), これもkharagan と「城砦長」を結び付ける傍証の1つとなり得る。城砦長は, バクトリア語文書 にさらに 2 名登場し（IPNB II/7, no. 277, 393），捺印物の銘文からも1名知られているが (Lerner et al. 2009, 224; SARC 2, AA 10.5; cf. IPNB II/7, no. 416)，これらの人物がkharaganであったかどうかは分からない。城些という 行政区画に関しては, 文書中に在証例が極めて少なく, 詳細は分からないが, shahroや §dagoの中にあった主邑で あった可能性がある。宮本 2015, 295, 299-301も参照。

（26）この他にも, kharagan と kharの父子関係を示すと思われる事例が1点存在したが, 最新の研究ではこの父子関 係には疑問が呈されている (IPNB II/7, no. 285 ii, 348; Sims-Williams and de Blois 2018, 75-76)。

（27）ソグドにおける地主や大商人などの有力者は，漢語文献において「大首領」と呼ばれたていたことが知られて いる（吉田 2011a, 32-33）。最近になって中国の延安市で，吐火羅出身の羅何含なる人物の墓誌が発見されており， そこではこの人物の祖父が皇（吐？）火羅の「大首領」であったと記されている（段 2014）。

(28) 倉庫管理人 (ambaro-birsarlogo) という職名は, 後半の-birsarlogo という要素の語源が良く分かっていない (BD II, 191a)。一方, 別の文書（Doc. eh）にも在証される前半部分のambaro-については, トゥムシュク語の hampara と比較できるかもしれない。ただし，近年発表された新出契約文書の研究では，「倉庫」という訳語が提案されて いたこの hamparaについて，何らかの資産と解釈するに留められている（荻原，慶 2014, 14, 24-25）。 
であるが, 若干の考察が可能である。

バクトリア語文書には, Doc. eg 以外にもう1点, 書記長に言及する契約文書が存在し, その末尾 には次のように記されている（Sims-Williams 2015, 42-43）：「これは書記である私Bredagによって， 書記長 $\mathrm{Oz}$ の命により，書かれた」。ここでは，書記長の命によって文書が書かれたとあり，契約文 書の作成において重要な役割を担っていたと考えられる。バクトリア語文書には書記長に関するこ れ以上の情報はないが, ここで思い起こされるのは, トルファン出土のソグド語女奴隷売買文書 (639 年）の末尾に見える次の文言である（吉田他 1989, 6; 吉田 2011b, 95）:「この女奴隷文書は, パター ワルの息子のウフワーンによって書かれた。書記長であるパターワルの認可によって, ウフシュー ビルトの命令により, ウパーチュの同意を得て」。ここに見える書記長パターワルは「高昌の書記長」 と名乗っており，高昌国で高い地位にあったことが知られているが，残念ながらソグド本土におけ る書記長がどのような役割を果たしていたのかは分かっていない。しかしいずれにしても，書記長 が契約の締結に際して重要な役割を担っていたことは確かである。

さらに, サーサーン朝や先述の高昌国の事例から判断すれば, トハーリスターンに抏ける書記長 も, 契約締結のみならず, 様々な職務を担い, 支配者の側近として活動していたと思われる。貴族 階層である kharaganに属する人物が書記長であったことは, この点を示唆していよう。

最後に, kharaganという語が比較的古い時代の文書にのみ現れることに注意を喚起しておきたい。 年代の分かる文書のうち, 最も古い文書は 357 年のDoc. Aa, 最も新しいものは 472 年のDoc. Hで ある。吉田豊が指摘するように, Doc. J以降, 在地の有力者やkhar 自身がShaburan という家名を 用いるようになり, この家名を持つ捺印物も知られている (Yoshida 2003, 159a; cf. Docs. J, L, N, P, Q,

W; SARC 2, AA 12.3, AA 13.2)。しかし, kharaganから Shaburanへの変化の要因は全く分からない。

\section{III. おわりに}

以上，バクトリア語文書群を利用し，トハーリスターンの在地社会における支配階層について考 察した。不明な点が多く残されているが, 本稿を, トハーリスターン, ひいてはソグドやコータン など，中期イラン語が使用されていた社会の実相を解明するための研究の新たな出発点としたい。 そして, このような断片的な研究を積み重ね, 最終的には, 不明な点の多いイスラーム化以前の中 央アジアの歴史を解明することに結び付けてゆきたい。

（29）前イスラーム時代，とりわけサーサーン朝における書記に関しては，Tafazzoli 1993; Tafazzoli 2000, 18-37を 参照。

（30）ほぼ同じ文言が別の契約文書の末尾にも見える（Doc. ab）：「この契約書は, 私Azad-fardarによって, Weshladの命により，書かれた」。ここには書記長という職名が見えないが, 先に挙げた文書と比較すれば, Wesh-ladが 書記長であったことは間違いないだろう。

(31) 高昌国の書記長については, 荒川 1990, 140-145; 荒川 2010, 56-57を参照。ムグ山文書とアフラシアブの壁画 に見える書記長については，Bogoljubov and Smirnova 1963, 43-47; Livshits 2015, 159-160, 237-247を参照。

（32） kharaganのSartからの手紙Doc. xc（年代不明）に付されていたと思しき捺印物には, Sart Shaburanという銘 文があった可能性が指摘されている (IPNB II/7, no. 421; Lerner \& Sims-Williams 2011, 197)。これは, Doc. xcの 捺印物に見える胸像が, Sart Shaburan という銘文を持つ別の捺印物（SRAC 2, AA 13.2）の胸像と酷似しているこ

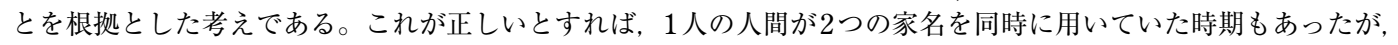
その後, kharaganが用いられなくなったことになる。 


\section{付記}

本稿は科学研究費（16J05995）による成果の一部である。

\section{略号一覧}

BD I²: Sims-Williams 2012a

BD II: Sims-Williams 2007

BD III: Sims-Williams 2012b

IPNB II/7: Sims-Williams 2010

SARC 2: Lerner and Sims-Williams 2011

\section{参照文献}

de Blois, F. 2008: "Du nouveau sur la chronologie bactrienne post-héllenistique: 1'ère 223-224 ap. J.-C.," Comptes rendus de l'Académie des Inscriptions et Belles-Lettres 2006/2, 991-997.

Bogoljubov, M. N. and O. I. Smirnova 1963: Sogdijskje Dokumenty s Gory Mug III: Xozjajstvjennyje Dokumjenty, Moskva.

Gyselen, R. 1989: La géographie administrative de l'Empire sassanide. Les témoignages sigillographiques, Paris.

Gyselen, R. 2002: Nouveaux materiaux pour la géographie historique de l'empire Sassanidse: Sceaux administratifs de la collection Ahmad Saeedi, Paris.

Gyselen, R. 2007: Sasanian Seals and Sealings in the A. Saeedi Collection, Acta Iranica 44, Leuven.

Khan, G. 2007: Arabic Documents from Early Islamic Khurasan, London.

de la Vaissière, É 2010: “Note sur la chronologie du voyage de Xuanzang,” Journal Asiatique 298/1, 157-168.

de la Vaissière, É 2016: “KUSHANSHAHS i. History,” Encyclopaedia Iranica, Online edition, http://www.iranicaonline. org/articles/kushanshahs-01 (accessed on 15 March 2018).

Lerner, J. A. et al. 2009: "The Bactrian Sealings in the A. Saeedi Collection (London)," in Ph. Gignoux et al. (eds.) Trésors d'Orient. Mélanges offerts à Rika Gyselen, Paris, 211-235.

Lerner, J. A. and N. Sims-Williams 2011: Seals, Sealings and Tokens from Bactria to Gandhāra (4 ${ }^{\text {th }}$ to $8^{\text {th }}$ century), Studies in the Aman ur Rahman Collection, vol. 2, Wien.

Livshits, V. A. 2015: Sogdian epigraphy of Central Asia and Semirech'e, London.

Marshak, B. 1994: "DĒWĀŠTīČ," Encyclopadia Iranica VII/3, 334-335.

Schindel, N. 2016: “KUSHANSHAHS ii. Kushano-Sasanian Coinage,” Encyclopadia Iranica, Online edition, http:// www.iranicaonline.org/articles/kushanshahs-02-coinage (accessed on 15 March 2018).

Sims-Williams, N. 1997: New Light on Ancient Afghanistan: The Decipherment of Bactrian, London.

Sims-Williams, N. 2007: Bactrian Documents from Northern Afghanistan II: Letters and Buddhist Text, London.

Sims-Williams, N. 2008: “The Sasanians in the East: A Bactrian archive from northern Afghanistan," in V. S. Curtis and S. Stewart des., The Sasanian Era, London/New York, 88-102.

Sims-Williams, N 2009: “KADAGISTĀN,” Encyclopadia Iranica XV/3, 324-325.

Sims-Williams, N. 2010: Bactrian Personal Names. Iranisches Personennamenbuch II/7, Wien.

Sims-Williams, N. 2011: “Turks and other peoples in the Bactrian documents," in Ölmez, M. et al. eds. Ötüken'den Istanbul'a. Türkçenin 1290 Yılı (720-2010), Istanbul, 15-26.

Sims-Williams, N. 2012a: Bactrian Documents from Northern Afghanistan I: Legal and Economic Documents (revised edition), London.

Sims-Williams, N. 2012b: Bactrian Documents from Northern Afghanistan III: Plates, London.

Sims-Williams, N. 2015: “A Bactrian document from southern Afghanistan? (with an appendix by Étienne de la Vaissière)," Bulletin of the Asia Institute n.s. 25, 39-53. 
Sims-Williams, N. and F. de Blois 2018: Studies in the Chronology of the Bactrian Documents from Northern Afghanistan, Wien.

Tafazzoli, Ah. 1993: “DABĪR i. In the Pre-Islamic Period,” Encyclopaedia Iranica VI/5, 534-537.

Tafazzoli, Ah. 1994: "DEHQĀN,” Encyclopaedia Iranica VII/2, 225-226.

Tafazzoli, Ah. 2000: Sasanian Society, New York.

Vondrovec, K. 2014: Coinage of the Iranian Huns and their Successors from Bactria to Gandhära ( $4^{\text {th }}$ to $6^{\text {th }}$ century CE), 2 vols., Wien.

Yoshida, Y. 2003: "Review of N. Sims-Williams, Bactrian Documents from Northern Afghanistan I, 2000" Bulletin of the Asia Institute n.s. 14, 154-159.

荒川正晴 1990 :「トルファン出土「麹氏高昌国時代ソグド文女奴隷売買文書」の理解をめぐって」『神戸市外国語大 学外国学研究』21, 137-153.

荒川正晴 2010 ：『ユーラシアの交通・交易と唐帝国』名古屋大学出版会.

荻原裕敏, 慶昭蓉 2014 : 「新出トゥムシュク語契約文書について」『内陸アジア言語の研究』29,7-53.

桑山正進（訳注）1987：『大唐西域記』大乗仏典中国・日本篇9, 中央公論社.

段志凌 2014 : 「陝西延安新出土唐吐火羅人羅何含墓誌」『文物』2014/8,63-68.

濱田正美 1993 :「「塩の義務」と「聖戦」との間で」『東洋史研究』52/2, 274-300.

宮本亮一 2014:『バクトリア史研究』博士論文, 龍谷大学 (http://hdl.handle.net/10519/5671 最終閲覧2018年 3 月 15 日). 宮本亮一 2015 :「トハーリスターン行政地理研究序説」『東方学報』90, 320-277.

吉田豊 1999:「中央アジアオアシス定住民の社会と文化」間野英二（編）『アジアの歴史と文化』8中央アジア,同朋舎, $42-54$.

吉田豊 2011a：「ソグド人とソグドの歴史」曽布川寛, 吉田豊（編）『ソグド人の美術と言語』臨川書店, 7-78.

吉田豊 2011b :「ソグド人の言語」曽布川寛, 吉田豊『ソグド人の美術と言語』臨川書店, 79-118.

吉田豊 2013 :「バクトリア語文書研究の近況と課題」『内陸アジア言語の研究』28, 39-65.

吉田豊 2017:「コータンのユダヤ・ソグド商人？」土肥義和, 気賀澤保規（編）『敦煌・吐魯番文書の世界とその時代』 東洋文庫, 263-285.

吉田豊他 1989 :「麹氏高昌国時代ソグド文女奴隷売買文書」『内陸アジア言語の研究』4, 1-50. 